ments being developed jointly by a Stanford/Louisiana State University/Rome group), there is also the prospect of experiments in space with masses a long distance apart, distances being monitored by laser interferometry. Weber may not have detected gravity pulses, but by inspiring the work of the past two years around the world he has ensured that there is now a real prospect of making the final push to produce detectors sensitive at the levels which relativity theory suggests will be suitable for the detection of such radiation. Just as the steady state theory provided the incentive for work which ultimately led to convincing evidence in favour of bigbang models, so Weber's incorrect interpretation of the events detected by his apparatus may prove the first step in the detection of pulses in line with relativity theory.

\section{TROPICAL ECOLOGY}

\section{Fire and Savanna}

from a Correspondent

IN 1952 P. W. Richards (The Tropical Rain Forest, Cambridge University Press) expressed the general view that the savanna grasslands of Africa, and their recent rapid spread south of the Sahara at the expense of closed forest, are wholly ascribable to the increased incidence of man-induced fire rather than to climatic conditions and a recent increase in aridity. These African savannas have been described as the largest area of mismanaged land in the world, yet fire can be exploited judiciously as a management tool. On April 9 the Tropical Group of the British Ecological Society met to discuss recent research on the effects of burning on savanna vegetation and animal populations.

Dr R. Rose-Innes (Land Resources Division, Overseas Development Administration) described how firing early in the dry season induces a mild burn favoured by silviculturists; the intense late burns encourage grassland at the expense of forest, and burns after the first rain can destroy the woody vegetation as it begins to shoot. Dr. R. M. Lawton (Land Resources Division, ODA) elaborated the use of fire in forest management; Dr R. H. Kemp (Commonwealth Forestry Institute, Oxford) pointed out, however, that savanna regions could provide $10-20$ times their present yield per hectare of hardwood timber if planted with tropical pines. The use of photogrammetry for interpreting patterns of savanna burning in relation to climate, soils and agricultural practice was summarized by Dr R. P. Moss (University of Birmingham), and Dr A. Blair Rains (Land Resourcs Division, ODA) described its use for estimating grazing resources in the semi-arid regions of Southern Africa where grass is too sparse to support a fire detrimental to woody growth.

Professor M. R. Delany (University of Southampton) and $\operatorname{Dr}$ B. R. Neal (University of Saskatchewan) studied the effect of fire on small rodent populations in Uganda's Queen Elizabeth Park. Twelve species were found, if considered by three size categories, to occupy specific niches defined by microhabitat, food resources and feeding behaviour; responses to fire differ, but there is an initial increase in numbers, after which a drastic decline and eventual recovery follows. Small mammals favour the cover of tall grasslands, and their numbers and diversity are inversely proportional to those of large mammals which favour the more nutritious short grasslands.

Contributions by Professor D. H. N.
Spence (University of St Andrews) and Dr G. Harrington (CSIRO, Canberra) on burning and grazing in relation to deterioration of habitat diversity in two Ugandan national parks emphasized the impression gained at the meeting as a whole: fire, the old scourge of African savanna, is being overtaken by the new spectre of overgrazing, especially by elephants. In parts of East Africa fire exclusion leads to no appreciable amelioration of deforestation unless grazing is also excluded; the old traditional use of fire-arms, and the prevalence of tsetse, in West Africa has so far prevented overgrazing, but with the elimination of tsetse it can be anticipated. Dr Kemp's dream of productive softwood forestry in African savanna therefore remains a long way off, while in the Brazilian savannas the new highway is leading to a rate of forest devastation never before witnessed.

\title{
More Very Old Rocks from Greenland
}

THE oldest known rocks in the world are quartzofeldspathic gneisses (the Amîtsoq gneisses) from the Godthaab area of West Greenland which were dated in the range $3,700-3,750$ million years by members of the group at the University of Oxford in collaboration with the Geophysical Survey of Greenland (Black et al., Earth Planet Sci. Lett., 12, 245; 1971 and Moorbath et al., Nature Physical Science, 240, 78 ; 1972). In next Monday's Nature Physical Science (May 14), members of the same team (Pankhurst et al.) report further rubidium-strontium ages from this part of Greenland, although the new ages represent a more recent event in the evolution of the Godthaab area.

The rocks in question are the Nûk gneisses which lie in close association with Amîtsoq gneisses but which occur as dykes and subconcordant sills cutting the older rocks and as large subconcordant complexes. Most of the samples now dated by Pankhurst and his colleagues are from a large polyphase complex of quartzofeldspathic rocks in which the earlier phases are dioritic and the later ones granitic. The interpretation given for the Nûk gneisses is that they are derived from a syntectonic suite of calc-alkaline igneous rocks which were intruded into the Amîtsoq gneisses and the Malene supracrustals (metavolcanics and metasediments) which postdate them. Conversion to gneisses then took place by metamorphism and deformation both during and subsequent to, the intrusion of the parent rocks.

The Nûk gneisses dated are from the north of Godthaab where they are metamorphosed to the same degree as the associated Amîtsoq gneisses and Malene supracrustals. The metamorphic grade is, however, significantly lower than that to the south of Godthaab where the 3,700-3,750 million year old Amîtsoq gneisses were obtained. For this reason the rubidium-strontium isochron age for the Nûk gneisses is thought to represent the time of crystallization of the igneous parent material rather than the time of later isotopic rehomogenization associated with metamorphism.

The age obtained by Pankhurst et al. is $3,040 \pm 50$ million years, which gives another fixed point on the time scale for the crustal evolution of West Greenland. Thus the plutonic development giving rise to the parent rocks of the Amîtsoq gneisses, the conversion of the parent rocks to gneisses, the intrusion of a basic dyke swarm (the Ameralik dykes) into the gneisses, the production of the Malene supracrustals, and the intercalation of the Amîtsoq gneisses and the Malene supracrustals, must all have taken place in the interval from about 3,700 to 3,000 million years ago.

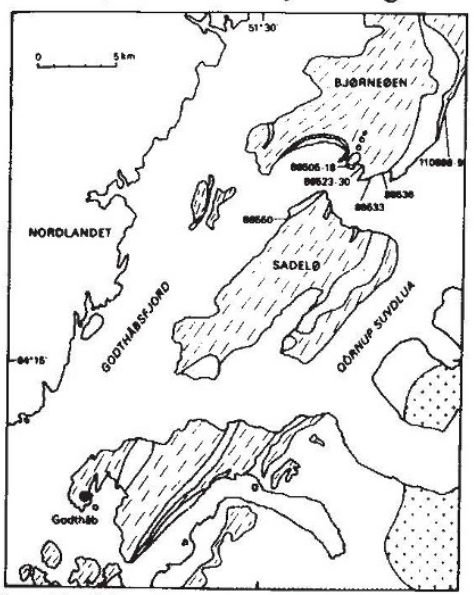

The Godthaab region of West Greenland. The Nûk gneisses are represented by diagonal dashes, the Amîtsoq ones by the stippled pattern. 